This is a draft essay which may differ substantially from any future published version. Copyright (C) James Miller 2012. All Rights Reserved. Visit www.jamesmiller.ca

\title{
Nature, Impersonality, and Absence in the Theology of Highest Clarity Daoism
}

\author{
James Miller
}

Excerpted and slightly adapted with the author's permission from The Way of Highest Clarity: Nature, Vision and Revelation in Medieval China (Magdalena, NM: Three Pines Press 2008).

Abstract: This essay describes salient features of the theological vision of the Way of Highest Clarity (Shangqing Dao), a Daoist religious movement that began in the late fourth century of the common era. The tradition emphasized the visualuazation of gods in the body, and the correspondence between bodies, mountains and stars. The essay focusses on the theological representation space, in particular, the inner spaces of the body, the inner spaces of the earth, and the outer space of the heavens. It argues, based on an original reading of primary sources, that Highest Clarity Daoists imagined these locative absences as the "ways-through" or pervasions of the ultimate metaphysical absence of the Dao.

The Way of Highest Clarity (Shangqing dao 上清道) flourished for a thousand years in medieval China from the fourth to the fourteenth centuries. It was a distinct branch of the Daoist religion formed around its own scriptural revelation transmitted under the authority of a lineage of forty-five patriarchs. Although it no longer exists in any overt institutional form, its practices were absorbed into the mainstream Daoist traditions that continue to this day. It thus constitutes an important link between the earliest organized religious traditions that emerged in the latter Han (25-220) and the modern forms of Daoism that were developed from the Yuan dynasty (1279-1368) onwards.

It originated in a series of revelations from a variety of "perfected persons," former human beings who had been transfigured into powerful celestial gods. The revelations from these gods were written down in texts which describe lush celestial paradises inhabited by a vast panoply of divine personages served by "jade maidens" and "lads," and who lived a life of sumptuous luxury and ease. The texts also explain that the way to this Heaven of Highest Clarity consists in repeating the process by which these perfected beings were revealed in the first place: namely, by mentally visualizing their descent from heaven and their entry into the body of the individual. This can occur at the specific times and places when the vast and obscure operations of the cosmos make this contact possible.

Through this process of visualization, the transformative powers of the gods are once again revealed, and the body of the adept is transfigured into the same type of perfected being who revealed these celestial worlds in the first place. The adept's body then avoids death completely and, while still alive but in a transfigured state, ascends to heaven in broad 
This is a draft essay which may differ substantially from any future published version. Copyright (C) James Miller 2012. All Rights Reserved. Visit www.jamesmiller.ca

daylight, leaving behind no earthly token. Those who do not manage to achieve this transfiguration die but, through the intervention of perfected beings, may be reborn in paradise as "immortals." Such persons obtain a position within the celestial hierarchy inferior to that of the perfected beings, but nonetheless avoid much of the trauma experienced by those condemned to a post-mortem existence in the underworld. Those unfortunates are tortured, tried and punished by sadistic officials in the three bureaux of heaven, earth and water in order to work off the accumulated guilt of their misdeeds, and they are separated from their friends and family. Such a fate is to be avoided at all costs. ${ }^{2}$

The Way of Highest Clarity thus regards humans as living in a space between the biological process of earth and the constellated spiritual powers of the heavens. Within the hierarchy of the cosmos, humans rank above the animal world, but below the heavenly world. But because natural law is understood as a law of transformation, Highest Clarity Daoists believe that it is possible to change one's fundamental nature in an act of cosmic transfiguration and, as it were, metamorphose from one's earthly status to that of a celestial being. Again it is important to understand that although this involves transcending the ordinary givenness of human life in a literal and metaphorical ascension to the stars, this is not, strictly speaking, a supernatural process, because the heavens are governed by the same laws of nature as every other part of the created order. Bodily ascension, though rare and wondrous, is understood as a wholly natural transformation of the body that is open to anyone who had been initiated into the scriptures and who has the dedication to pursue the methods they detail.

\section{Natural Gods}

To understand more precisely how the tradition regarded the celestial realm of gods and spirits as the part of the natural, rather than supernatural, realm, it is necessary to examine the theology of Highest Clarity in more detail. The key point here is that whereas in the Western traditions, the world of gods and heavens is understood as being supernatural, that is to say, beyond the normal operation of the laws of nature, in Highest Clarity Daoism, this is not the case: both gods and humans are subject to the same universal law, the pattern of the Dao. In the classical Abrahamic faiths, the reverse is the case. God is transcendent. Nature exists in the way that it does because of God, whether nature is understood as the divine

\footnotetext{
${ }^{1}$ The precise meaning of the term immortal (xian 仙) is widely contested among different movements and historical periods within the Daoist tradition. In the Highest Clarity texts under discussion in this book, the term has a specific meaning in terms of the ranking of various classes of "immortals" within the celestial realms, and is always considered inferior to the "perfected person" (zhenren 真人).

2 Unlike the Celestial Masters tradition, which specified in great detail the functioning of the underworld, many Highest Clarity texts do not tend to focus on this, preferring instead to emphasize the benefits of a life in paradise (see Robinet 1984: 1.66). A detailed discussion of the evolution of ideas concerning the afterlife in early medieval China, and their relationship to Buddhist concepts of death and rebirth, can be found in Bokenkamp (2007).
} 
This is a draft essay which may differ substantially from any future published version. Copyright (C) James Miller 2012. All Rights Reserved. Visit www.jamesmiller.ca

"Word" of the Torah, the logos of Johannine theology, or in terms of the natural philosophy of Islamic scholasticism. In Daoism, the opposite is true.

Nature, or to be more precise, human observation of natural processes, provides the template for the theological imagination. Consequently there can be no absolute disjunction between the processes of earth and the processes of the heavens. The gods are significant because they embody the fundamental abstractions of natural processes even better than human beings. ${ }^{3}$

But the second consequence of this (to Western thought) inverted view of the relationship between theology and nature, is that personality is not a strong feature of Highest Clarity Daoist gods. Although the tradition has many anthropomorphic gods, these gods are not to be explained in terms of their histories and actions, as are the various gods of the Hebrew scriptures or Greek mythology. In the European and West Asian religious traditions what becomes important about the various gods is their (all-too-human) characteristics: gods are important precisely for the personal qualities that they embody. Gods are loving, just, merciful, wise, faithful, jealous, capricious, powerful, or treacherous. In short they are analogous to human beings, and though they may have superhuman powers they retain entirely human personalities. But in Highest Clarity Daoism, my argument is that gods are important not because of their analogy to humans but because of their analogy to nature. In particular, the impersonality and impassivity of nature are the gods' most powerful attributes, and the higher up the pantheon, the more abstract, impassive and inhuman the gods become. Gods are important not because they are loving or kind, but because, as instantiations of the Dao, they are compelled to follow inexorably the fundamental laws or patterns of the cosmos.

To explain this argument requires investigating the connection between religious ritual and natural law in Highest Clarity Daoism. Here it is important to distinguish two distinct religious strains that are evident in the tradition: that of the bureaucratic theological tradition and that of the personal religious encounter. Highest Clarity Daoism combines these two emphases. The initial revelations of gods as described by Yang Xi are often described in intimate terms like that of a marriage. However, as the tradition developed, the influence of the bureaucratic tradition of formal encounters with the gods came to the fore. The Highest Clarity texts discussed in this book clearly imagine ritual encounters with their gods as

\footnotetext{
3 This helps explain why Daoism never developed a strong creation narrative similar to the narratives of Genesis or Gilgamesh. There was no need to explain how the gods created the natural world, because it was impossible to conceive of the gods as existing outside or beyond those natural processes. For this reason many people speak of the Dao, that is to say, the ultimate creative process of the cosmos, as being an immanent, rather than a transcendent process, and offer a sharp contrast with the transcendent deity of the Western traditions. Strictly speaking, however, the language of transcendence and immanence cannot be applied to the Daoist cosmos because such a language automatically implies the possibility of something existing outside or beyond the natural world. Even to say that the Dao is immanent in nature implies necessarily the difference between the Dao and nature, and such a view could never be entertained within the conceptual vocabulary of Daoism.
} 
This is a draft essay which may differ substantially from any future published version. Copyright (C) James Miller 2012. All Rights Reserved. Visit www.jamesmiller.ca

formal, bureaucratic encounters, rather than personal, intimate unions. Here is a typical example from the Yellow Venerable Lord of the Center's Eight Secret Sayings of the Dao:

On the day Spring Begins and the jia[zi] and yi[chou] days of the first month, in the early morning look to the north. There will be purple, green and white clouds, which are the Three Pure Feathered Clouds of the Supreme Three Pure Ladies. At this time the Three Primes take the eightbearer chariot, ascending to visit the Supreme Emperor of Heaven. Following them you will see the three-colored clouds. At this time you must visualize in your mind knocking your head to the floor and striking yourself. Visualize in your mind making four double bows, [then] present yourself and beg as follows:

"A certain great-grandson has a degree of love for the Way and its Power and has cultivated the [Way of] the Nine Perfected, purified his five spirits and has also brought about the perception of the Imperial Lord of Heaven. Let it be recorded today that he has had an auspicious encounter with the Three Prime Lords while out on their travels and pleads to be granted the service of a chariot. He prays for the satisfaction of his desires."

If you see the carriages of the Prime Lords three times, then you will ascend to immortality in broad daylight and will have no further need of visual meditation. Whatever [you desire] will be granted. Practicing the Eight [Secret Sayings of the] Dao's words of blessing and obeisance are also like this. This is what is known as the Eight Secret Sayings of the Dao. Only those who possess an immortal register should hear about it. (trans. Miller 2008: 201)

There are many interesting elements in this passage that are commented on in detail in the translation, but for the present purposes it is important to focus on the parallels with courtly ritual. The ultimate goal of this encounter is ascending to immortality in broad daylight. This is achieved by being sent a "chariot" of clouds from heaven which will take the adept back into the skies. The chariot is sent after a visual encounter with a high-ranking deity who has the power to send the clouds. It involves submitting before him, making a petition couched in formal court language and having the details of the encounter officially recorded. Many passages in the Highest Clarity Daoist texts evoke similar courtly themes to this. Daoist adepts present petitions to the gods as one might do to an emperor. The gods are addressed respectfully by their titles, as one might address an official from whom one sought a favor. The gods are imagined wearing courtly dress, living in luxurious palaces, waited on by servant boys and girls. Highest Clarity Daoists also symbolize immortality in terms of being ennobled by the court and presented with letters of title to that effect. 
This is a draft essay which may differ substantially from any future published version. Copyright (C) James Miller 2012. All Rights Reserved. Visit www.jamesmiller.ca

From this analysis it might seem more obvious to interpret the heaven of Highest Clarity by analogy with the imperial court, the gods by analogy with emperors, and the religious ritual by analogy with courtly ritual. If all this were true, then it would make more sense to say that the world of Highest Clarity is an eminently human world, a personal and social world, rather than a world of natural law and cosmic forces. In fact this is precisely the stumbling block that many interpreters of Daoism have had to deal with in attempting to see the connection between the natural philosophy of The Way and Its Power (Daode jing 道德 經) and the bureaucratic, legalistic and godly world of Daoist religion. In my analysis, what is at stake in this question is how one understands the gods. If the gods are like human beings, and the religious communications like personal correspondence, then it is indeed difficult to connect Highest Clarity Daoism with the natural philosophy of The Way and Its Power. However, it is my argument here that Highest Clarity Daoism is indeed directly linked to the natural philosophy of The Way and Its Power through the Daoist bureaucratic theological tradition and that, as the tradition matured and developed beyond the original revelations in southern China, the gods came to be understood more by analogy with natural forces than human personalities.

This is not to discount the absolutely significant role played by intimate encounters with personal gods, such as those described in the compilation of Highest Clarity revelations, known as Declarations of the Perfected (Zhen'gao 真告). Clearly such personal encounters aided in the advancing of individual causes with regards to the afterlife and can be understood proximately in social and personal terms. However, my argument here is that an equally important strand of Highest Clarity practices envisages encounters with gods in an impersonal way that is concerned with bringing about the full flourishing of the cosmos. In the practices detailed in the texts in this book, the thoroughly personal and social relationships established between humans and the gods serve an altogether metaphysical and cosmic purpose that transcends the mundane concerns of the living and the dead. ${ }^{4}$

Consider, first of all, the purpose of the ritual, namely being assumed bodily into heaven. This is conceived as an act within the realm of the natural world, though it involves a radical transfiguration of nature, that is to say reconfiguring nature so as to achieve some ultimate transformation. This process of natural transfiguration bears a close connection to the alchemical tradition, which sought physical immortality through the refining and ingestion of natural substances. Note further that ascension is not a reward for moral activity: heaven is not a place where the good are rewarded for their virtuous actions.

\footnotetext{
${ }^{4}$ Readers who are interested to learn more about the social world of Highest Clarity religion should consult Bokenkamp (2007).
} 
This is a draft essay which may differ substantially from any future published version. Copyright (C) James Miller 2012. All Rights Reserved. Visit www.jamesmiller.ca

Ascension here is granted as a result of engaging and petitioning the gods of heaven who live in the starry sky above to be admitted into their fold. In short the text couches the transfiguration of nature in the form and language of the court. To put it another way, the process of ascension should not be understood as a "natural" metaphor for some transformation within the social realm. That would be a thoroughly modern Durkheimian misreading of what the Highest Clarity adepts envisage they are doing. ${ }^{5}$ Rather, for the Highest Clarity adept, the courtly imagery is the metaphorical element in this ritual; the deeper reality to which it points is the transfiguration of nature. Nature is not a symbol for some deeper social or spiritual reality; rather the courtly imagery is the symbolic vehicle for the transformation of natural reality. ${ }^{6}$

Thus while Highest Clarity ritual is proximately concerned with the social, legal and political ordering of the conventional world, it also aims towards a higher religiosity. This higher religiosity is based on engaging the seemingly implacable forces of nature that govern the fundamental horizons of human existence, namely the processes of birth and death. And while the ritual formulas for engaging with these processes bear a strong resemblance to the court ritual of the Confucian state, the ultimate goal is clearly Daoist, rather than Confucian, for the whole panoply of ritual is directed towards human interaction with the powers of nature.

Secondly, it is necessary to consider more carefully the courtly way in which the gods are described. Although the description of the gods can be quite detailed-riding chariots, trailing clouds and wearing various brocade vestments - nothing of this description is in any way personal. Rather, it all related to official function: these gods are not personalities but bureaucrats. Similarly the courtly ritual is not a personal encounter but rather a form of official correspondence. Gods are not addressed by their name, nor do they have any personal

\footnotetext{
5 To explain this concept further it might also be useful to make a distinction between Daoist and Confucian ritual. The ritual of the Confucian court is bound up in the importance of convention. For Confucian ritual theorists, such as Xunzi, what is important about the world of human civilization is its pure conventionality. Humans manage their interactions through language and culture in ways that are wholly arbitrary and independent of their natural forces and inclinations. Xunzi most clearly argued this when he observed that rain falls independently of whether humans pray for it or not. That is to say, the world of religion and ritual are, in his view, absolutely distinct from the laws of nature. In this regard his views are similar to the Deists of early modern Europe who argued that the providence and goodness of deity lies not in the biblical god's intervention in human salvation history, but in his providential ordering of the laws of the universe so as to facilitate the overall flourishing of the human enterprise. In Xunzi's view, therefore, religious and courtly ritual is important not because it influences the heavens to be more disposed to the specific needs of human beings, but because of its effect in knitting together human societies in ways that are, overall, productive. In this regard, his view may be compared to that of Durkheim, for whom the ultimate object of religion is not any putative god or gods but rather society itself.

6 The supplementary question that this raises is why did the practitioners of Highest Clarity deem it necessary to construct and imagine their ultimate religious goal in these terms? The answer must be sought in the social-historical reality of the world of Highest Clarity practitioners.
} 
This is a draft essay which may differ substantially from any future published version. Copyright (C) James Miller 2012. All Rights Reserved. Visit www.jamesmiller.ca

dwelling or personal characteristics. They are addressed by their title, in their official residence, wearing official vestments, about matters to do with their official function. It matters not in the slightest who they actually are, if indeed these gods have any individuality to them. The only thing that matters is their official capacity.

Here the connection to nature becomes even more evident, for what distinguishes the function of someone in an official capacity and someone in a personal capacity is that the bureaucrat is compelled by his official nature to function in accord with the laws of the bureaucratic system of which he is an element. Without the system he has no official capacity at all; in such a case he would simply be an "ordinary person." But what gives the bureaucrat his power is that that he is not acting as an "ordinary person" but rather he subsumes his personality within his official function, thus becoming ideally "faceless."

Highest Clarity adepts do not generally call on the gods by their personal names, or pray to them as one's "heavenly father," but address them by their official title: "Imperial Lord" or "Supreme Unity." Whereas an important element of devotional religions is the intimate encounter between the adept and the god, calling the god by name, seeing his or her face and entering into a relationship based on love, this is precisely the opposite of what this bureaucratic aspect of Highest Clarity religion desires. The last thing that an adept wants is for the gods to exercise their power as a result of personal grace and favor. Should the gods start acting on the basis of whim or individual personality, the universe would become entirely capricious, and the religion would be indistinguishable from popular Chinese religion where people pray for good fortune in the gambling house. Yes, the gods are imagined as superhuman beings, but they are largely understood as impersonal, faceless and dispassionate superhuman beings who, unlike the wholly personal Buddhist bodhisattvas, do not operate on the basis of sympathy or compassion with the suffering of mortal humans.

Consider more closely the way in which the adept in this passage prays for the "satisfaction of his desires." He does not ask the god for mercy or for some kind of special treatment. He simply asks the god to recognize that he has done what is required of him. $\mathrm{He}$ has cultivated his person, purified his spirit and visualized the gods. The basis of his request is thus that he is officially qualified and legally entitled to achieve immortality. The purpose of the petition is thus not to beg the god for mercy, but to recognize and validate the legitimacy of the petitioner's actions. The god has no choice in this matter inasmuch as he is discharging his official function as a celestial bureaucrat. He has to comply with the request because it is made in accordance with what is legally required. But unlike the earthly bureaucrat who is carrying out the law that is the expressed will of the sovereign or, in a democracy, the expressed will of the people, the celestial bureaucrat is carrying out the law of the Dao. This law is not the expression of divine will but simply the law of nature, understood as the 
This is a draft essay which may differ substantially from any future published version. Copyright (C) James Miller 2012. All Rights Reserved. Visit www.jamesmiller.ca

economy of cosmic power that governs the transactions between Daoist adepts and the heavens.

This points to another fundamental distinction between Chinese and West Asian theology. In the West Asian theological system, the god of the Bible and the Koran expresses his divine power through his will. In the Torah, the Biblical god chooses to be the god of the Israelites just because he decides to choose them and not others, and issues laws that the Israelites have to comply with in return for being the chosen people. In the Koran, similarly, humans must submit to the divine will as expressed in the revelation to the Prophet precisely because it is the expression of the divine will. There appears, however, to be no such possibility for voluntarism in Highest Clarity Daoist theology. ${ }^{7}$ There is a law, but no lawgiver; and there is a creation, but no creator. Thus in such a system, although gods may have the appearance of humans and may act in ways that bear a formal correspondence to human actions, the underlying principle that governs these gods is not personality or humanity but rather impersonality and the natural law of the cosmic economy.

This "impersonality" does not describe the whole range of human-divine encounters within the Highest Clarity tradition. ${ }^{8}$ Highest Clarity Daoism emerged as a synthesis of southern Chinese spirit-medium religion with Daoist visions of nature and bureaucracy and thus incorporates many different kinds of theological approaches. However, in this historical religious synthesis the impersonal bureaucratic tradition played the dominant role, and the intimate encounters of spirit-mediums such as Yang Xi with Highest Clarity goddesses were not spiritual ends in themselves. By the time of the Highest Clarity patriarch Zhu Ziying's (976-1029) preface to the Perfect Scripture of the Great Grotto, the tradition had become firmly located within the impersonal metaphysics of the Dao.

Highest Clarity Daoists thus employ the rich web of courtly ritual and legalistic language in order to address themselves to and effect some transfiguration within, the vital power of the cosmos. To do so requires first of all conceiving of the vital power of the cosmos as functioning according to some law or principle and, secondly, that that principle must contain within itself the notion of correspondence or reciprocity between the human world and the cosmos. The latter principle establishes the possibility of effective engagement with the ultimate forces of the universe - that they are in some way disposed to respond to human activity. The former principle establishes the possibility of some kind of formulaic,

\footnotetext{
${ }^{7}$ Indeed, if possessing a personal will is a requirement for the definition of godhood, then in Highest Clarity Daoism we are not dealing with gods at all, and the word "theology" cannot apply. However, this strongly personalist and voluntarist reading of deity is not the only way to read gods in general, or the Abrahamic god in particular. The difference, however, is that while voluntarism is a legitimate theological option in West Asian theologies, it is not at all in Highest Clarity Daoist theology.

${ }^{8}$ For a discussion of Highest Clarity spirituality that more clearly falls within the rubric of intimate spiritual encounters, see Kroll (1996) and Bokenkamp (1996).
} 
This is a draft essay which may differ substantially from any future published version. Copyright (C) James Miller 2012. All Rights Reserved. Visit www.jamesmiller.ca

systematic engagement with these forces of the cosmos, rather than the ad hoc activities of unstructured popular religion.

These two principles form the condition for the possibility of Highest Clarity religious ritual, that is to say, universal formulas for effective correspondence with the divine. Ritual prescribes the basic formula or template for correspondence between the adept and the god, a correspondence conceived as a formal encounter. The formality, or formulaic nature, of ritual is key because it ensures that the personality of the individual and, indeed, the personality of the god are entirely irrelevant to the process of spiritual transformation. Again, this is exactly the opposite of the "personal spirituality" of the modern West, in which the personal beliefs and moral feelings of the individual are key to the successful religious life. But in Highest Clarity Daoism, individual belief and feeling are subsumed under the systematic, equalizing power of ritual formulas.

The Highest Clarity view of "natural ritual" points towards a view of nature not as a collection of objects, but rather as a collection of powers who extended their influence through a variety of pathways or "daos." To return to the earlier discussion of fluids and solids, Daoists generally hold fluids to be the foundation of nature, which operates according to the binary rhythm of yin and yang, a view that goes back to the Zhou dynasty Book of Changes (Zhouyi 周易). The basic principle of yin and yang is that of an eternal, immutable correspondence, which is exactly the same presupposition for imagining religious rituals as pathways of fluid communication between the various elements of the cosmos. But how exactly are yin and yang understood as key phases within the fluidity of nature? A treatise on yin and yang in the Yellow Emperor's Internal Classic, Simple Questions (Huangdi neijing suwen 黃帝內經素聞) helps to explain these categories:

Heaven arose out of the accumulation of yang; the earth arose out of the accumulation of yin. Yin is tranquility, yang is agitation; yang creates, yin stimulates development; yang kills, yin stores. Yang transforms influences, yin completes form. (Unschuld 1985: 283)

This extract demonstrates that yin and yang are not understood either as objects, or, indeed, as forces, but as modes of activity. When the text describes yang as "agitation," and yin as "tranquility" it means that when considering the dynamics of action there are always two modes: activity, which means extending influence or power outwards; and tranquility, which means receiving external influences and absorbing them internally. Tranquility here does not mean that nothing is going on; rather it means that no external projection of force is happening. When something is in its yin mode it is "completing form," which means it is absorbing and processing the external influence that it has received. 
This is a draft essay which may differ substantially from any future published version. Copyright (C) James Miller 2012. All Rights Reserved. Visit www.jamesmiller.ca

When a stone is thrown into a pond, the water first exhibits activity as it responds to the stone with waves. This is yang. As time passes, however, turbulence subsides and the water gradually returns to its normal state. This is yin. Another way of thinking about this is in terms of breathing. Yang is exhaling, or expiration; yin is in inhaling, or inspiration. The nature of yang (expiration) is thus to transform something else, whereas the nature of yin (inspiration) is to receive and store form. When yang and yin are put together then we begin to see nature as a dynamic process in which influence or power is constantly being extended outwards and absorbed internally. The result of this constant processing or exchanging of power is what we call nature, that is, the fluid world of change. Nature is thus conceived as correspondence and transformation, just like the ritual exchanges of bureaucratic Daoism.

Since nature is thus the visible result of the constant dynamic of exchange, this immediately makes it clear why correspondence is so important in the Highest Clarity Daoist world. Without correspondence - the mechanism of extending influence and being influenced - there can be no dynamism; without dynamism, there can be no life. And from this definition it follows that life can only be understood as transformation, the constant exercise of power between correspondent "entities" and the transformation of those "entities" by this process of correspondence.

Furthermore, for the Highest Clarity adept, the significance of nature does not lie in any particular form that it has achieved, that is to say, any particular "entity" but rather in the spaces in between forms, that is to say the channels of influence and media of exchange that make the dynamism of nature possible. In other words, the spaces between things make this correspondence and transformation possible. Without space, there would simply be inert matter, or "dead stuff." With space, there can be the possibility of correspondence, interaction and transformation.

\section{Absent Nature}

Investigating the philosophy of nature in Highest Clarity Daoism thus takes us from the ordinary phenomenal world through the hidden conduits of communication to the heart of the transformative power of the cosmos, to the Way itself. A theme repeated throughout the texts of Highest Clarity is the importance of emptiness, or empty space, as the location of creative transformation. Take, for example, the sermon that the Highest Clarity perfected Zhou Ziyang preached when he received his celestial title:

The [part of] heaven [where there is] nothing is called space. The [part of] the mountain [where there is] nothing is called a grotto. The [part of the] human [body where there is] nothing is called a [grotto] chamber. The empty spaces in the mountains and organs of the body are called grotto courts. The empty spaces in human heads are called grotto chambers. This is 
This is a draft essay which may differ substantially from any future published version. Copyright (C) James Miller 2012. All Rights Reserved. Visit www.jamesmiller.ca

how the perfected take up residence in the heavens, the mountains and human beings. When they enter the place of nothingness, a grain of rice could contain Mt. Penglai and embrace the sixfold harmony [of the cosmos], yet heaven and earth would not be able to contain them. (trans. Miller 2008: 152)

This sermon demonstrates that the nature of space and the relationship between nothingness and emptiness constitute the chief pre-occupation of the newly perfected person. Whereas Buddhist metaphysics conceives of emptiness in terms of ontology and psychology, it is clear that this Daoist metaphysical teaching dwells on the existential, locative nature of space. The spaces of the heavens, the mountains and the body are all alike. They partake in the same character of nothingness ( $w u$ 無) which is precisely what enables them to be places of residence ( $c h u$ 處) for the perfected.

Zhou Ziyang's progress along the Way, therefore, is an encounter with nothingness, which takes place in emptiness. The spaces in the mountains enable him to encounter the teachers who reveal texts to him. The spaces in the body enable him to visualize the gods of his body. The nature of this Daoist nothingness or empty space is that it transcends all place, or as the text puts it, "a grain of rice could contain Mt. Penglai and embrace the six harmonies, yet heaven and earth would not be able to contain it." Empty space is thus a space of connection, enabling the communicative reciprocity between the various dimensions of the universe and consequently the transformation of things.

This understanding of the creative significance of empty space is corroborated in the Preface to the Perfect Scripture of the Great Grotto. Although the majority of this text can be read as a philosophical reflection on the correlation between the Way and the revelation of scriptures, the opening stanzas begin by considering the significance of absence and nonbeing:

Now, the Way is born from nonbeing, secretly harboring a multitude of numinous powers, which no-one can fathom. Spirits condense in the void, marvelously transforming in myriad ways without bounds. In the darkest depths, there is an essence, serene and stable, which shines out light. This great mystery is infinite, reaching across the void, preserving stillness. This is called the "Great Grotto." (Trans. Miller 2008: 213)

Zhu Ziying, the Highest Clarity patriarch who composed this preface, here defines the Way in terms of three key elements: nonbeing ( $w u$ 無), emptiness ( $x u$ 虛) and mystery (xuan 玄). It is important to understand these key images. All three refer in some way to the idea of absence that Zhu Ziying holds to be at the center of things. 
This is a draft essay which may differ substantially from any future published version. Copyright (C) James Miller 2012. All Rights Reserved. Visit www.jamesmiller.ca

The concept of the absence of being is familiar throughout Daoism and can be traced back as far as The Way and Its Power. Chapter eleven offers the most familiar and fullest description of this nonbeing:

Thirty spokes are united in one hub.

It is in its [space of] emptiness,

where the usefulness of the cart is.

Clay is heated and a pot is made.

It is in its [space of] emptiness,

where the usefulness of the pot is.

Doors and windows are chiseled out.

It is in its [spaces of] emptiness,

where the usefulness of a room is. (Moeller 2007: 27)

These images all point to a relationship between the empty space and its enclosing object. The object depends on the empty space for its form and, thereby, its "usefulness." The insight offered by Hans-Georg Moeller, however, is that this "structural blueprint" depends on the concept of enclosure, something that surrounds the emptiness. This then points us figuratively towards the concept of rotation. The form surrounds, that is, revolves metaphorically and literally around the empty space that it encloses. This concept is clearest in the image of the wheel, with its spoke rotating around an "empty" hub, but it is also true in terms of the pot, which one can imagine being spun on a potter's wheel and also by extension the walls of the room "rotating" around the empty space.

Moeller is drawing on the insight of the Chinese scholar, Pang Pu 庞朴 (1995), into the genesis of the cosmological term xuan 玄 conventionally translated as "mystery" or "darkness." Pang argues that this term originally referred to a "whirling," as one can see pictographically in the Chinese character. This came subsequently to mean a "deep or dark mystery" when it was used to describe the downward spiraling of water. Putting these two insights together, we can begin to see that the root image of the Dao is thus something like a downward swirling void, around which things come into being.

Returning to Zhu Ziying's metaphysical pronouncements, we can detect this "swirling void" in three dimensions. Firstly, the Dao itself is understood as the ontological predication of being on the swirling void of nonbeing. All the beings that exist depend for the existence on the ontological absence ( $w u$ 無) on which they are predicated.

Secondly, this ontological absence entails a locative emptiness ( $x u$ 虛), that is to say, the concrete form of empty spaces throughout the universe. In Highest Clarity Daoism these 
This is a draft essay which may differ substantially from any future published version. Copyright (C) James Miller 2012. All Rights Reserved. Visit www.jamesmiller.ca

"empty spaces" are understood as conduits for spiritual powers. Spirits reside in these "vacuums," which is to say that the hidden powers of the cosmos exercise their transformative capacity in these interstitial spaces, the various "emptinesses" of caverns in nature and cavities in the brain. Without these empty spaces, spiritual transformation and creativity could not take place; there would simply be inert matter.

Thirdly, this relationship between being and nonbeing, between presence and absence, is understood as the "great mystery" (taixuan 太玄) or "vast cosmic swirling" of the Dao. This combination of stillness and splendor, darkness and light, is, for Zhu Ziying, summed up in the term Great Grotto or "Vast Pervasion." The "vast pervasion" is the one no/thing that unites all forms together: all beings are predicated on the same nonbeing; all presences are predicated on the same absence; all forms are predicated on the same emptiness. Emptiness pervades all beings, uniting them in the one "great mystery," the abysmal, swirling, metaphysical absence of the Dao itself. This, then, is the hollow root of nature, the empty source in which all beings partake, continuously communicating power and effecting transformation among the myriad creatures of the cosmos.

\section{References}

Bokenkamp, Stephen R. 1996. "Declarations of the Perfected." Pp. 16-179 in Religions of China in Practice, edited by Donald S. Lopez, Jr. Princeton: Princeton University Press.

2007. Ancestors and Anxiety: Daoism and the Birth of Rebirth in China. Berkeley: University of California Press.

Miller, James. 2008. The Way of Highest Clarity: Nature, Vision and Revelation in Medieval China. Magdalena, NM: Three Pines Press.

Moeller, Hans-Georg. 2007. Daodejing (Laozi): A Complete Translation and Commentary. Chicago and La Salle, IL: Open Court.

Pang Pu 庞朴. 1995. “Tan xuan”談玄 [Discussing Mystery]. Pp. 284-294 in Yi fen wei san: Zhongguo chuantong sixiang kaoshi一分為三：中國傳統思想考試 [One Becomes Three: Examinations of Traditional Chinese Thought]. Shenzhen: Haitian. 